\title{
ANALISIS FAKTOR-FAKTOR RISIKO YANG MEMPENGARUHI KINERJA MUTU PADA PROYEK KONSTRUKSI DI ACEH UTARA
}

\author{
S. Malasyi ${ }^{1)}$, A. Rauzana ${ }^{2)}$, M. Afifuddin ${ }^{3)}$ \\ ${ }^{1,2,3)}$ Magister Teknik Sipil, Universitas Syiah Kuala, Banda Aceh \\ Email: syibralmalasyi91@gmail.com ${ }^{1)}$, anrauzana@gmail.com ${ }^{2)}$. \\ afifuddin64@gmail.com ${ }^{3)}$
}

DOI: http://dx.doi.org/10.29103/tj.v11i1.432

(Received: December 2020 / Revised: January 2021 / Accepted: January 2021)

\begin{abstract}
Abstrak
Kegagalan konstruksi merupakan kegagalan yang dapat disebabkan karena kegagalan pada proses pengadaan barang atau jasa, atau kegagalan dapat juga terjadi saat proses pelaksanaan konstruksi. Dalam pelaksanaannya, proyek konstruksi yang tidak menggunakan aspek pengendalian dapat menyebabkan kegagalan konstruksi (failure constructions). Oleh sebab itu menetapkan sebuah standar manajemen mutu proyek (project quality management) dalam suatu proyek konstruksi adalah hal yang sangat dibutuhkan. Populasi yang diambil dalam penelitian ini hanya sebanyak 80 perusahaan, dengan menggunakan persamaan slovin didapat responden sebanyak 45 perusahaan. Data yang dibunakan adalah data primer dilakukan dengan cara penyebaran kuesioner kepada kontraktor pelaksana proyek kontruksi dengan sebanyak 45 perusahaan secara tertutup. Data primer di analisis dengan regresi linear berganda. Hasil penelitian penelitian faktor -faktor risiko yang sangat berpengaruh di tetapkan pada salah satu faktor risiko yang mempunyai mean tertinggi. Dalam analisis memperlihatkan bahwa dari 6 faktor - faktor risiko yang diteliti, yang memiliki mean tertinggi terdapat pada faktor risiko perencanaan yaitu sebesar 4,33. Hasil uji t faktor sumber daya manusia, faktor material, faktor peralatan faktor manajemen berpengaruh signifikan terhadap mutu proyek sedangkan faktor keuangan dan faktor perencanaan tidak berpengaruh signifikan terhadap kinerja mutu proyek. Berdasarkan analisis uji $\mathrm{F}$ pengaruh variabel secara simultan faktor - faktor risiko berpengaruh signifikansi terhadap mutu proyek konstruksi di Aceh Utara.
\end{abstract}

Kata Kunci: faktor-faktor risiko, mutu proyek

\begin{abstract}
Construction failure is a failure that can be caused due to failure in the process of procuring goods or services, or failure can also occur during the construction process. In its implementation, construction projects that do not use control aspects can cause construction failures (failure constructions). Therefore, establishing a project quality management standard in a construction project is very much needed. The population taken in this study is only 80 companies, using the Slovin equation obtained respondents as many as 45 companies. The data used are primary data carried out by distributing questionnaires to contractors implementing construction projects with as many as 45 companies in private. Primary data were analyzed using multiple linear regression. The results of the research research the very influential risk factors are determined on one of the risk factors that has the highest mean. The analysis shows that of the 6 risk factors studied, the one with the highest mean is the planning risk factor, which is 4.33 . The results of the t test of human resource factors, material
\end{abstract}


factors, equipment factors, management factors have a significant effect on project quality, while financial factors and planning factors have no significant effect on project quality. Based on the analysis of the $\mathrm{F}$ test, the simultaneous influence of the risk factors has a significant effect on the quality of construction projects in North Aceh.

Keywords: risk factors, project quality.

\section{Latar Belakang}

Kegagalan konstruksi merupakan kegagalan yang dapat disebabkan karena kegagalan pada proses pengadaan barang atau jasa, atau kegagalan dapat juga terjadi saat proses pelaksanaan konstruksi. Kegagalan pekerjaan konstruksi adalah keadaan hasil pekerjaan konstruksi yang tidak sesuai dengan spesifikasi pekerjaan sebagaimana disepakati dalam kontrak kerja konstruksi baik sebagian maupun keseluruhan sebagai akibat dari kesalahan pengguna jasa atau penyedia jasa. Dalam pekerjaan konstruksi bangunan sering ditemukannya kegagalan bangunan yang dapat diakibatkan oleh pihak penyedia jasa atau pengguna jasa. Semua pekerjaan konstruksi melakukan pergerakannya sesuai dengan tahapan (siklus) kegiatannya yaitu diawali dengan perencanaan, sifat bahan bangunan yang digunakan, pengujian bahan dan bangunan/konstruksi, pelaksanaan dan pengawasan serta pemeliharaan bangunan (Arsana, 2016).

Faktor penyebab kegagalan konstruksi sangat dimungkinkan terjadi pada industri konstruksi, karena industri konstruksi sangat kompleks, banyak pihak yang terlibat, prosesnya di alam terbuka. Kegagalan konstruksi dan kegagalan bangunan dapat disebabkan oleh kompetensi sumber daya baik kompetensi badan usaha, kompetensi keahlian maupun kompetensi keterampilan. Antara lainnya faktor tenaga kerja menjadi salah satu penyebab dari kegagalan konstruksi, yaitu penempatan tenaga kerja harus disesuaikan antara keahlian tertentu sehingga pekerjaan yang dihasilkan menjadi efisien dan efektif (Arsana, 2016). Tanpa sumber daya manusia ini tidak akan dihasilkan apa-apa pada pekerjaan pembangunan proyek konstruksi. Dengan demikian perencanaan, penyiapan dan distribusi penyediaan sumber daya dengan susunan dan jumlah yang tepat akan sangat menunjang keberhasilan pelaksanaan yang ada. Kontribusi tenaga kerja terhadap kelancaran sebuah proyek tergantung kehalian dan motivasinya (Dian Tjundoko, 2011). Menurut (Triana and Oktavianto, 2013) Komponen komponen yang mendukung kualitas pekerjaan adalah kualifikasi kontraktor yang memiliki modal, sumber daya peralatan, sumber daya manusia, dan pengalaman perusahaan. Jika kemampuan kontraktor terbatas, sudah dapat dipastikan bahwa hasil yang dicapai dibawah standar kualitas.

Proyek konstruksi yang tidak menggunakan aspek pengendalian dapat menyebabkan kegagalan konstruksi (failure constructions). Oleh sebab itu menetapkan sebuah standar manajemen mutu proyek (project quality management) dalam suatu proyek konstruksi adalah hal yang sangat dibutuhkan. Baik pada proyek skala besar, menengah maupun proyek skala kecil manajemen mutu proyek mutlak ada. Manajemen mutu proyek mencakup proses dan aktivitas kinerja organisasi proyek yang menentukan kebijakan mutu, tujuan, dan tanggung jawab sehingga proyek akan memenuhi kebutuhan yang dimilikinya (Morris, 2013). Oleh sebab itu di perlukan penelitian untuk mengetahui faktor-faktor risiko yang mempengaruhi kinerja mutu pada proyek kontruksi di Aceh Utara. 


\section{Metode Penelitian}

\subsection{Subjek dan Populasi}

Subjek pada penelitian ini yaitu pendekatan permasalahan dengan mengindentifikasi variabel risiko yang mempengaruhi kinerja mutu pada proyek konstruksi di Aceh Utara. Objek penelitian ini adalah bagi pelaksana proyek konstruksi dan pihak-pihak yang terkait dengan proyek .

\subsection{Teknik Penentuan Sampel}

(Amirin, 2011) Menjelaskan populasi adalah kumpulan dari keseluruhan pengukuran, objek, atau individu yang sedang dikaji. Jadi pengertian populasi dalam statistik tidak terbatas pada sekelompok/kumpulan orang-orang, namun mengacu pada seluruh ukuran, hitungan, atau kualitas yang menjadi fokus perhatian suatu kajian.Target populasi dalam penelitian ini adalah penyedia jasa (kontraktor) yang aktif mendapatkan pekerjaan yaitu (direktur dan site manager). Penyedia jasa kualifikasi K1, K2, K3, M1 dan M2 berdasarkan yang terdaftar pada lembaga Pengembangan Jasa Kontruksi (LPJK) Provinsi Aceh Tahun 2020.

\subsection{Teknik Pengumpulan Data}

Menurut (Sugiyono, 2015) Setelah kuesioner selesai disusun, maka langkah selanjutnya yaitu melakukan penyebaran kuesioner kepada responden. Tujuan dilakukan penyebaran kuesioner adalah untuk memperoleh persepsi responden mengenai faktor risiko yang mempengaruhi kinerja mutu proyek konstruksi. Langkah-langkah yang dilakukan dalam melakukan penyebaran kuesioner ini yaitu sebagai berikut:

1. Meyiapkan kuesioner untuk ditujukan kepada responden yaitu yang berbentuk pertanyaan - pertanyaan yang sudah ada pilihan jawabannya

2. Menginventarisir jumlah konstraktor yang ada di Aceh Utara sebanyak 45 perusahaan.

3. Mencari waktu yang tepat untuk penyebaran kuesioner

4. Menyebarkan dan mengumpulkan kuesioner penelitian sesuai dengan waktu yang telah direncanakan.

Tabel 1 Daftar Pertanyaan Untuk Responden (Direktur/ Site Manager)

\begin{tabular}{|c|c|c|c|c|c|c|c|}
\hline \multirow{2}{*}{ Variabel } & \multirow{2}{*}{ No. } & \multirow{2}{*}{ Pernyataan - Pernyataan } & \multicolumn{5}{|c|}{ Penilaian } \\
\hline & & & 1 & 2 & 3 & 4 & 5 \\
\hline \multirow{10}{*}{$\begin{array}{l}\text { Faktor Sumber } \\
\text { Daya Manusia } \\
\qquad\left(\mathrm{X}_{1}\right)\end{array}$} & 1. & Bekerja tidak sesuai prosedur & & & & & \\
\hline & 2. & Kurangnya jumlah tenaga kerja & & & & & \\
\hline & 3. & Kurangnya pengalaman kerja & & & & & \\
\hline & 4. & Lambatnya penyediaan tenaga & & & & & \\
\hline & 5. & Kurangnya pengetahuan kerja & & & & & \\
\hline & 6. & Kurang produktivitas tenaga kerja & & & & & \\
\hline & 7. & Kedisiplinan tenaga kerja kurang & & & & & \\
\hline & 8. & Kurangnya Pengetahuan Tentang & & & & & \\
\hline & 9. & KurangTenaga Kerja Pada Bidang & & & & & \\
\hline & 10. & Kurang Pemahaman Tentang & & & & & \\
\hline
\end{tabular}




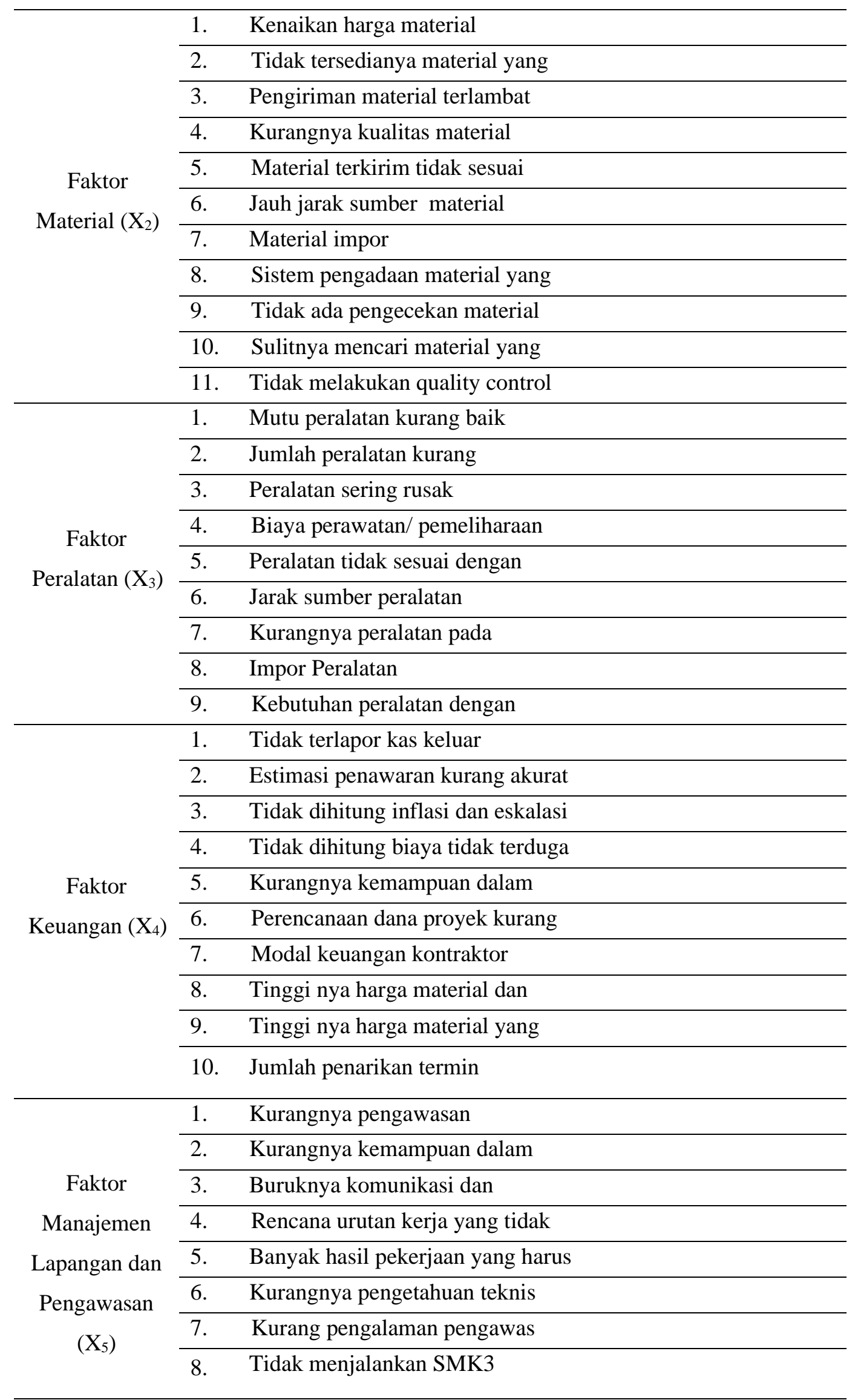




\begin{tabular}{cll}
\hline & \multicolumn{1}{l}{ 1. } & Tidak detailnya gambar \\
\cline { 2 - 3 } & 2. & Tidak ada rencana mutu \\
\cline { 2 - 3 } Faktor & 3. & Tidak lengkapnya identifikasi \\
\cline { 2 - 3 } $\begin{array}{cl}\text { Perencanaan } \\
\left(\mathrm{X}_{6}\right)\end{array}$ & L. & Lambat merevisi dan \\
\cline { 2 - 3 } & 6. & Hasil perencana tidak mengerti material \\
\cline { 2 - 2 } & 7. & Kurangnya pengetahuan teknis \\
\hline & 8. & Tidak detail dalam perencanaan \\
\hline & 9. & Kesalahn dalam perhitungan \\
\hline
\end{tabular}

Kuesioner yang disebar dibuat menggunakan skala likert. Jawaban dari setiap item instrumennya menggunakan skala likert yang akan diberi skor untuk keperluan analisis kuantitatifnya. Jawaban tersebut adalah sebagai berikut: Tidak Berpengaruh sama dengan 1, Berpengaruh Rendah sama dengan 2, Berpengaruh Sedang sama dengan 3, Berpengaruh sama dengan 4,dan Sangat Berpengaruh sama dengan 5 (Riduwan, 2014). Untuk lebih jelas daftar pertanyaan disajikan pada Tabel 1

\subsection{Teknik Analisis Data}

Menurut (Indriani, 2010) Regresi linier berganda berguna untuk mendapatkan pengaruh dua variabel kriterium atau untuk mencari hubungan fungsional dua prediktor atau lebih dengan variabel kriteriumnya atau untuk meramalkan dua variabel prediktor atau lebih terhadap variabel kriteriumnya. Analisis data ini menggunakan analisis regresi linear berganda sebagai metode dalam pengolahan data dan digunakan regresi linear berganda untuk melihat pengaruh atau tidak berpengaruh variabel bebas dengan variabel terikat dengan menggunakan persamaan regresi. Regresi linear berganda digunakan dengan menggunakan bantuan program SPSS. Koefisien regresi dari masing - masing variabel di masukkan dalam persamaan. untuk lebih jelas Persamaan regresi yang yang digunakan adalah sebagai berikut.

$$
Y=a+b_{1} x_{1}+b_{2} x_{2}+b_{3} x_{3}+b_{4} x_{4}+b_{5} x_{5}+b_{6} x_{2}
$$

di mana:

$$
\begin{array}{ll}
\mathrm{Y}_{1} & =\text { Mutu proyek } \\
\mathrm{X}_{1} & =\text { Sumber daya manusia } \\
\mathrm{X}_{2} & =\text { Material } \\
\mathrm{X}_{3} & =\text { Peralatan } \\
\mathrm{X}_{4} & =\text { Keuangan } \\
\mathrm{X}_{5} & =\text { Manajemen lapangan } \\
\mathrm{X}_{6} & =\text { Perencanaan } \\
\mathrm{a} & =\text { Konstanta } \\
\mathrm{b}_{1} & =\text { Koefisien Sumber daya manusia } \\
\mathrm{b}_{2} & =\text { Koefisien Material } \\
\mathrm{b}_{3} & =\text { Koefisien Peralatan }
\end{array}
$$




$$
\begin{array}{ll}
\mathrm{b}_{4} & =\text { Koefisien Keuangan } \\
\mathrm{b}_{5} & =\text { Koefisien Keuangan } \\
\mathrm{b}_{6} & =\text { Koefisien Perencanaan } \\
\sum \mathrm{x} & =\text { Jumlah nilai item } \mathrm{x} \\
\sum \mathrm{y} & =\text { Jumlah nilai item } \mathrm{y} \\
\mathrm{N} & =\text { Jumlah responden }
\end{array}
$$

\section{Hasil dan Pembahasan}

\subsection{Karakteristik Responden (Perusahaan)}

Menurut (Raco, 2018) bahwa karakteristik responden adalah keadaan atau identitas yang melekat pada responden. Karakteristik responden dalam penelitian ini dilihat dari berbagai aspek seperti kualifikasi ijin usaha, jumlah

\begin{tabular}{|c|c|c|c|}
\hline No. & $\begin{array}{c}\text { Karakteristik Responden (Perusahaan) } \\
\text { Direktur/ Site Manager }\end{array}$ & Frekuensi & Persentase \\
\hline \multirow[t]{8}{*}{1} & Kualifikasi ijin usaha perusahaan & & \\
\hline & a. Bangunan Gedung & 38 & $84,40 \%$ \\
\hline & b. Bangunan Sipil & 7 & $15,60 \%$ \\
\hline & c. Instalasi Mekanikal dan Elektrikal & - & $0,00 \%$ \\
\hline & d. Jasa pelaksana lainnya & - & $0,00 \%$ \\
\hline & e. Jasa pelaksana spesialis & - & $0,00 \%$ \\
\hline & f. Jasa pelaksana keterampilan & - & $0,00 \%$ \\
\hline & Jumlah & 45 & $100 \%$ \\
\hline \multirow[t]{6}{*}{2} & Dalam 5 tahun terakhir jumlah proyek dikerjakan & & \\
\hline & a. $0-10$ & 43 & $96,60 \%$ \\
\hline & b. $10-20$ & 2 & $4,40 \%$ \\
\hline & c. $20-30$ & - & $0,00 \%$ \\
\hline & d. $>30$ & - & $0,00 \%$ \\
\hline & Jumlah & 45 & $100 \%$ \\
\hline \multirow[t]{7}{*}{3} & Kualifikasi perusahaan & & \\
\hline & a. $\mathrm{K} 1$ & 31 & $68,90 \%$ \\
\hline & b. $\mathrm{K} 2$ & 6 & $13,30 \%$ \\
\hline & c. $\mathrm{K} 3$ & 2 & $4,40 \%$ \\
\hline & d. $\mathrm{M} 1$ & 3 & $6,70 \%$ \\
\hline & e. $\mathrm{M} 2$ & 3 & $6,70 \%$ \\
\hline & Jumlah & 45 & $100 \%$ \\
\hline \multirow[t]{6}{*}{4} & Pengalaman di bidang konstruksi & & \\
\hline & a. $0-2$ Tahun & 25 & $55,60 \%$ \\
\hline & b. 2-5 Tahun & 15 & $33,30 \%$ \\
\hline & c. 5-8 Tahun & 3 & $6,70 \%$ \\
\hline & d. $>8$ Tahun & 2 & $4,40 \%$ \\
\hline & Jumlah & 45 & $100 \%$ \\
\hline
\end{tabular}
pekerjaan, kualifikasi perusahaan dan pengalaman perusahaan.

Karakteristik responden ini di maksudkan kepada penyedia jasa (kontraktor) di Aceh Utara yang diwakili oleh direktur dan site manager, dengan jumlah 45 perusahaan. Karakteristik responden diperlihakan pada Tabel 2.

Tabel 2 Karakteristik Responden 


\subsection{Hasil Uji Regresi}

Analisis regresi linear berganda ini digunakan untuk mengetahui pengaruh faktor - faktor risiko terhadap mutu pada proyek konstruksi di Aceh Utara. Model ini didapat dari hasil analisis dengan menggunakan aplikasi SPSS dan manfaat untuk mengetahui pengaruh faktor - faktor risiko terhadap kinerja mutu pada proyek konstruksi di Aceh Utara dengan variabel bebas (indenpendet variable) antara lain faktor sumber Daya manusia $\left(\mathrm{X}_{1}\right)$, faktor material $\left(\mathrm{X}_{2}\right)$, faktor peralatan $\left(X_{3}\right)$, faktor keuangan $\left(X_{4}\right)$, faktor keuangan $\left(X_{4}\right)$, faktor manajemen lapangan dan pengawasan $\left(\mathrm{X}_{5}\right)$, dan faktor perencanaan $\left(\mathrm{X}_{6}\right)$. Dari hasil model ini didapat tingkat pengaruh faktor - faktor risiko terhadapa kinerja mutu pada proyek konstruksi.

Tabel 3 Hasil Uji Model Regresi Linier Berganda

\begin{tabular}{lccc}
\hline \multicolumn{1}{c}{ Model } & \multicolumn{2}{c}{$\begin{array}{c}\text { Unstandardized } \\
\text { Coefficients }\end{array}$} & $\begin{array}{c}\text { Standardized } \\
\text { Coefficients }\end{array}$ \\
\hline Konstanta & $\mathrm{B}$ & Std. Error & Beta \\
\hline Faktor Sumber Daya Manusia $\left(\mathrm{X}_{1}\right)$ & -5.803 & 0,849 & \\
\hline Faktor Material $\left(\mathrm{X}_{2}\right)$ & 0,210 & 0,053 & 0,381 \\
\hline Faktor Peralatan $\left(\mathrm{X}_{3}\right)$ & 0,165 & 0,037 & 0,417 \\
\hline Faktor Keuangan $\left(\mathrm{X}_{4}\right)$ & 0,090 & 0,033 & 0,199 \\
\hline $\begin{array}{l}\text { Faktor Manajemen Lapangan dan } \\
\text { Pengawasan }\left(\mathrm{X}_{5}\right)\end{array}$ & $-0,097$ & 0,038 & $-0,199$ \\
\hline Faktor Perencanaan $\left(\mathrm{X}_{6}\right)$ & 0,193 & 0,041 & 0,409 \\
\hline
\end{tabular}

\subsection{Analisis Pengujian Validitas dan Reliabilitas}

Hasil uji validitas terhadap kuesioner pada tujuh variabel bebas dan variabel terikat yaitu faktor sumber daya manusia $\left(\mathrm{X}_{1}\right)$, faktor material $\left(\mathrm{X}_{2}\right)$, faktor peralatan $\left(\mathrm{X}_{3}\right)$, faktor keuangan $\left(\mathrm{X}_{4}\right)$, faktor manajemen lapangan dan pengawasan $\left(\mathrm{X}_{5}\right)$, faktor perencanaan $\left(\mathrm{X}_{6}\right)$ dan mutu proyek $(\mathrm{Y})$ yang di bagikan kuesioner kepada responden yaitu penyedia jasa konstruksi (kontraktor) di nyatakan valid karena nilai koefisien korelasi dari masing-masing varaibel tersebut lebih besar dari nilai kritis product moment pada level significant 5\% $(0,294)$ (Priyatno, 2010).

Hasil uji reliabilitas terhadap data kuesioner pada variabel faktor sumber daya manusia $\left(\mathrm{X}_{1}\right)$, faktor material $\left(\mathrm{X}_{2}\right)$, faktor peralatan $\left(\mathrm{X}_{3}\right)$, faktor keuangan $\left(\mathrm{X}_{4}\right)$, faktor manajemen lapangan dan pengawasan $\left(\mathrm{X}_{5}\right)$, faktor perencanaan $\left(\mathrm{X}_{6}\right)$ dan mutu proyek (Y) yang dihitung masing - masing diperoleh nilai alpha lebih besar dari standar alfa 0,60. Dengan demikian kuesioner yang digunakan dalan penelitian ini reliabel atau memenuhi aspek kehandalan (Priyatno, 2010).

\subsection{Analisis Regresi Linear Berganda}

Regresi linear berganda digunakan untuk mengetahui bentuk dan besarnya pengaruh antara faktor - faktor risiko terhadap kinerja mutu proyek konstruksi di Aceh Utara. Berdasarkan tabel 3.2, maka model regresi yang di peroleh yaitu: $\mathrm{Y}=-5,803+0,210 \mathrm{X}_{1}+0,165 \mathrm{X}_{2}+0,090 \mathrm{X}_{3}+(-0,097) \mathrm{X}_{4}+0,193 \mathrm{X}_{5}+(-0,107) \mathrm{X}_{6}$ Model ini didapat dari hasil analsis dengan menggunakan aplikasi SPSS dan 
manfaat untuk mengetahui pengaruh faktor - faktor risiko terhadap kinerja mutu pada proyek konstruksi di Aceh Utara dengan kinerja mutu proyek (Y) sebagai variabel terikat (dependent variable) yang di pengaruhi oleh 6 (enam) variabel bebas (indenpendet variable) antara lain faktor sumber Daya manusia $\left(\mathrm{X}_{1}\right)$, faktor material $\left(\mathrm{X}_{2}\right)$, faktor peralatan $\left(\mathrm{X}_{3}\right)$, faktor keuangan $\left(\mathrm{X}_{4}\right)$, faktor keuangan $\left(\mathrm{X}_{4}\right)$, faktor manajemen lapangan dan pengawasan $\left(\mathrm{X}_{5}\right)$, dan faktor perencanaan $\left(\mathrm{X}_{6}\right)$. Regresi pada model tersebut dapat di tafsirkan sebagai berikut:

1. Pengaruh faktor sumber daya manusia terhadap mutu pada proyek mempunyai koefisien regresi sebesar 0,210. Hal ini berarti bahwa faktor sumber daya manusia mempunyai pengaruh positif, dan bila ditingkatkan maka mutu pada proyek akan meningkat sebesar $21 \%$.

2. Pengaruh faktor material terhadap mutu pada proyek mempunyai koefisien regresi sebesar 0,165. Hal ini berarti bahwa faktor material mempunyaipengaruh positif, dan bila ditingkatkan maka mutu pada proyek akan meningkat sebesar $16,5 \%$.

3. Pengaruh faktor peralatan terhadap mutu pada proyek mempunyai koefisien regresi sebesar 0,090. Hal ini berarti bahwa faktor peralatan mempunyaipengaruh positif, dan bila ditingkatkan maka mutu pada proyek akan meningkat sebesar $9 \%$.

4. Pengaruh faktor keuangan terhadap mutu pada proyek mempunyai koefisien regresi sebesar -0,097. Hal ini berarti bahwa faktor-faktor keuangan mempunyai pengaruh negatif, dan bila ditingkatkan maka mutu pada proyek tidak meningkat.

5. Pengaruh faktor manajemen lapangan dan pengawasan terhadap mutu pada proyek mempunyai koefisien regresi sebesar 0,193. Hal ini berarti bahwa faktor manajemen lapangan dan pengawasan mempunyai pengaruh positif, dan bila ditingkatkan maka mutu pada proyek akan meningkat sebesar 19,3\%.

6. Pengaruh faktor faktor perencanaan terhadap mutu pada proyek mempunyai koefisien regresi sebesar -1,07. Hal ini berarti bahwa faktor faktor faktor perencanaan mempunyai pengaruh negatif, dan bila ditingkatkan maka mutu pada proyek tidak meningkat.

\subsection{Hasil Analisis Uji t Pengaruh Variabel Bebas Secara Parsial}

Dari hasil analisis uji $\mathrm{t}$ pengaruh variabel bebas secara parsial dapat dijelaskan sebagai berikut:

1. Hasil analisis pengaruh faktor sumber daya manusia $\left(X_{1}\right)$, secara parsial terhadap mutu pada proyek konstruksi diperoleh nilai t hitung untuk variabel faktor sumber daya manusia $\left(\mathrm{X}_{1}\right)$ sebesar 3,949 pada batasan nilai signifikansi 0,000. Nilai t tabel pada tingkat kesalahan 5\% adalah 1,686. Nilai t hitung lebih besar dari nilai t tabel sehingga $\mathrm{H}_{\mathrm{a} 1}$ diterima dan menolak $\mathrm{H}_{\mathrm{o}}$, faktor sumber daya manusia berpengaruh signifikan terhadap mutu pada proyek konstruksi di Aceh Utara.

2. Hasil analisis pengaruh faktor material $\left(\mathrm{X}_{2}\right)$, secara parsial terhadap mutu pada proyek konstruksi diperoleh nilai $\mathrm{t}$ hitung untuk variabel faktor material sebesar 4,431 pada batasan nilai signifikansi 0,000. Nilai t tabel pada tingkat kesalahan 5\% adalah1,686. Nilai t hitung lebih besar dari nilai t tabel sehingga 
$\mathrm{H}_{\mathrm{a} 2}$ diterima dan menolak $\mathrm{H}_{\mathrm{o} 2}$, faktor faktor material berpengaruh signifikan terhadap mutu pada proyek konstruksi di Kabupaten Aceh Utara.

3. Hasil analisis pengaruh faktor peralatan $\left(X_{3}\right)$, secara parsial terhadap mutu pada proyek diperoleh nilai t hitung untuk variabel faktor peralatan $\left(\mathrm{X}_{3}\right)$ sebesar 2,759 pada batasan nilai signifikansi 0,009. Nilai t tabel pada tingkat kesalahan 5\% adalah 1,686. Nilai t hitung lebih besar dari nilai t tabel sehingga $\mathrm{H}_{\mathrm{a} 3}$ diterima dan menolak $\mathrm{H}_{\mathrm{o}}$, faktor peralatan berpengaruh signifikan terhadap mutu pada proyek konstruksi di Kabupaten Aceh Utara.

4. Hasil analisis pengaruh faktor keuangan $\left(\mathrm{X}_{4}\right)$, secara parsial terhadap mutu pada proyek konstruksi di Kabupaten Aceh Utara. Dari hasil analisis regresi diperoleh nilai t hitung untuk variabel faktor keuangan sebesar -2,572 pada batasan nilai signifikansi 0,014 . Nilai t tabel pada tingkat kesalahan $5 \%$ adalah 1,686. Nilai t hitung lebih kecil dari nilai t tabel sehingga $\mathrm{H}_{\mathrm{a} 4}$ ditolak dan menerima $\mathrm{H}_{04}$, faktor keuangan tidak berpengaruh signifikan terhadap mutu pada proyek konstruksi di Kabupaten Aceh Utara.

5. Hasil analisis pengaruh faktor manajemen lapangan dan pengawasan $\left(X_{5}\right)$ secara parsial terhadap mutu pada proyek konstruksi di Kabupaten Aceh Utara. Dari hasil analisis regresi diperoleh nilai t hitung untuk variabel faktor manajemen lapangan dan pengawasan $\left(\mathrm{X}_{5}\right)$ sebesar 4,668 pada batasan nilai signifikansi 0,000 . Nilai t tabel pada tingkat kesalahan $5 \%$ adalah 1,686 . Nilai t hitung lebih besar dari nilai t tabel sehingga $\mathrm{H}_{\mathrm{a} 5}$ di terima dan menolak $\mathrm{H}_{\mathrm{o}}$, faktor manajemen lapangan dan pengawasan berpengaruh signifikan terhadap mutu pada proyek konstruksi di Aceh Utara.

6. Hasil analisis pengaruh faktor perencanaan $\left(\mathrm{X}_{6}\right)$, secara parsial terhadap mutu pada proyek konstruksi di Kabupaten Aceh Utara. Dari hasil analisis regresi diperoleh nilai $t_{\text {hitung }}$ untuk variabel faktor perencanaan $\left(\mathrm{X}_{6}\right)$ sebesar $-2,476$ pada batasan nilai signifikansi 0,014 . Nilai t tabel pada tingkat kesalahan 5\% adalah 1,686. Nilai $t$ hitung lebih kecil dari nilai t tabel sehingga $\mathrm{H}_{\mathrm{a} 4}$ ditolak dan menerima $\mathrm{H}_{04}$, faktor perencanaan $\left(\mathrm{X}_{6}\right)$ tidak berpengaruh signifikan terhadap mutu pada proyek konstruksi di Kabupaten Aceh Utara.

\section{Kesimpulan dan Saran}

\subsection{Kesimpulan}

Faktor risiko yang sangat berpengaruh terhadap kinerja mutu pada proyek konstruksi di Aceh Utara adalah faktor perencanaan. Faktor sumber daya manusia $\left(\mathrm{X}_{1}\right)$, faktor material $\left(\mathrm{X}_{2}\right)$, faktor peralatan $\left(\mathrm{X}_{3}\right)$, faktor keuangan $\left(\mathrm{X}_{4}\right)$, faktor manajemen lapangan dan pengawasan $\left(\mathrm{X}_{5}\right)$, faktor perencanaan $\left(\mathrm{X}_{6}\right)$ secara simultan berpengaruh signifikansi terhadap kinerja mutu proyek konstruksi di Aceh Utara.

\subsection{Saran}

Dalam penelitian ini didapat faktor perencanaan sangat berpengaruh terhadap kinerja mutu konstruksi di Aceh Utara dan semua faktor-faktor risiko berpengaruh signifakansi terhadap kenerja mutu proyek konstruksi, oleh karena itu, disarankan kepada penyedia jasa (kontraktor) untuk selalu memperhatikan faktor-faktor risiko dalam pelaksanan proyek konstruksi dilapangan. Disarankan kepada peneliti selanjutnya, untuk dapat mengembangkan dengan menggunakan faktor-faktor risiko yang baru dalam penelitian selanjutnya. 


\section{Daftar Kepustakaan}

Amirin, T.M., 2011. Populasi dan sampel penelitian. Rineka Cipta. Jakarta.

Arsana, I.P.J., 2016. Manajemen Pengadaan Barang dan Jasa Pemerintah. Deepublish.

Dian Tjundoko, 2011. Analisis Faktor - Faktor Penyebab Keterlambatan Waktu Proyek Konstruksi, Yogyakar.

Indriani, D., 2010. Regresi Linier Berganda.

Morris, P.W.G., 2013. Reconstructing project management. John Wiley \& Sons.

Priyatno, 2010. Teknik Mudah dan Cepat Melakukan Analisis Data Penelitian dengan SPSS dan tanya Jawab Ujian Pendadaran. Yogyakarta.

Raco, J., 2018. Metode penelitian kualitatif: jenis, karakteristik dan keunggulannya.

Riduwan, dan S., 2014. Pengantar Statistika untuk Penelitian Pendidikan, Sosial, Ekonomi, Komunikasi, dan Bisnis, Bandung.

Sugiyono, P.D., 2015. Metode penelitian pendidikan, Statistik Nonparamentris untuk Penelitia. Alfabeta, Bandung.

Triana, D., Oktavianto, W.O., 2013. Relevansi Kualifikasi Kontraktor Bidang Teknik Sipil Terhadap Kualitas Pekerjaan Proyek Konstruksi Di Provinsi Banten. Fondasi J. Tek. Sipil 2. 